\title{
3. Structural Imbalance, Inequality and Economic Growth
}

Xiaolu Wang and Yixiao Zhou

\section{Introduction}

A series of structural imbalances has persisted in the Chinese economy. The consumption rate has been declining for years and has been significantly lower than the international average, while the savings rate and the capital formation rate have been too high and continue to rise. Massive investment has caused the rapid expansion of production capacity, while consumption growth cannot keep up with the expansion of capital investment and production capacity, resulting in a sustained excess capacity. Without structural change, the Chinese economy will gradually lose momentum due to the deficiency of domestic demand.

Since the 2008 Global Financial Crisis (GFC), there has been a deceleration in China's economic growth rate. In the 1980s, China's economic growth was accelerated from the pre-reform period, reaching an average of 9.3 per cent per year. In the 1990s, China maintained an average growth rate of 10.4 per cent. During 2001-07, the average growth rate increased slightly to 10.8 per cent. Since then, however, the growth rate has been slowing. Between 2008 and 2011, the average growth rate dropped to 9.6 per cent per year. In both 2012 and 2013, the growth rate was 7.7 per cent. In the first quarter of 2014, the growth rate was only 7.4 per cent (NBS various years). The external reason for the slowdown in growth is weak demand from the international market; and the internal reason is the lack of domestic demand caused by the structural imbalances of the economy.

Insufficient domestic consumer demand results mainly from the imbalanced income distribution. This imbalance mainly results from an excessively large income gap and the imbalance of income distribution between the government, business and consumers. These are closely related to a series of institutional problems. Currently, the new Chinese leadership is promoting institutional reforms to address these issues. If these reforms can be successfully implemented, we can expect the downward trend in economic growth will gradually reverse in the next few years and growth is likely to be restored to 8 per cent. In the 
next 10 to 20 years, the Chinese economy will still have huge potential to remain in the fast lane. Of course, whether this optimistic scenario occurs will depend on how the reforms progress.

Section one of this chapter analyses the declining trend of the final consumption rate and its causes, and especially how it is affected by income distribution. Section two discusses the impact of structural imbalance on economic development and the potential for China to fall into the 'middleincome trap'. Section three discusses the effect of lowering savings and raising consumption to achieve the 'golden-rule savings rate' and what adjustments in income distribution are needed to make this happen.

\section{The impact of income distribution on consumption and saving}

According to official statistics, during the planned economy period from 1952 to 1978, there was a gradual increase in China's savings rate and a decrease in the consumption rate, which fell from 78.9 per cent to 62.1 per cent. At the beginning of the reform period, the consumption rate grew and reached 65-66 per cent in the mid 1980s, but then fell again, to 62.3 per cent, in 2000.

The consumption rate dropped significantly to 48.2 per cent during the next 10 years (2000-10), which was a reduction of 14.1 per cent; in the meantime, the share of household consumption in GDP fell from 46.4 per cent to 34.9 per cent. These were the lowest points of these two series since the 1950s. The savings rate rose to 51.8 per cent of GDP in 2010, which was a rare situation globally (NBS various years; World Bank 2014). It is only in the past couple of years that the consumption rate has rebounded slightly. Figure 3.1 shows the changes in the consumption rate, the savings rate and the capital formation rate in China in the past six decades. 


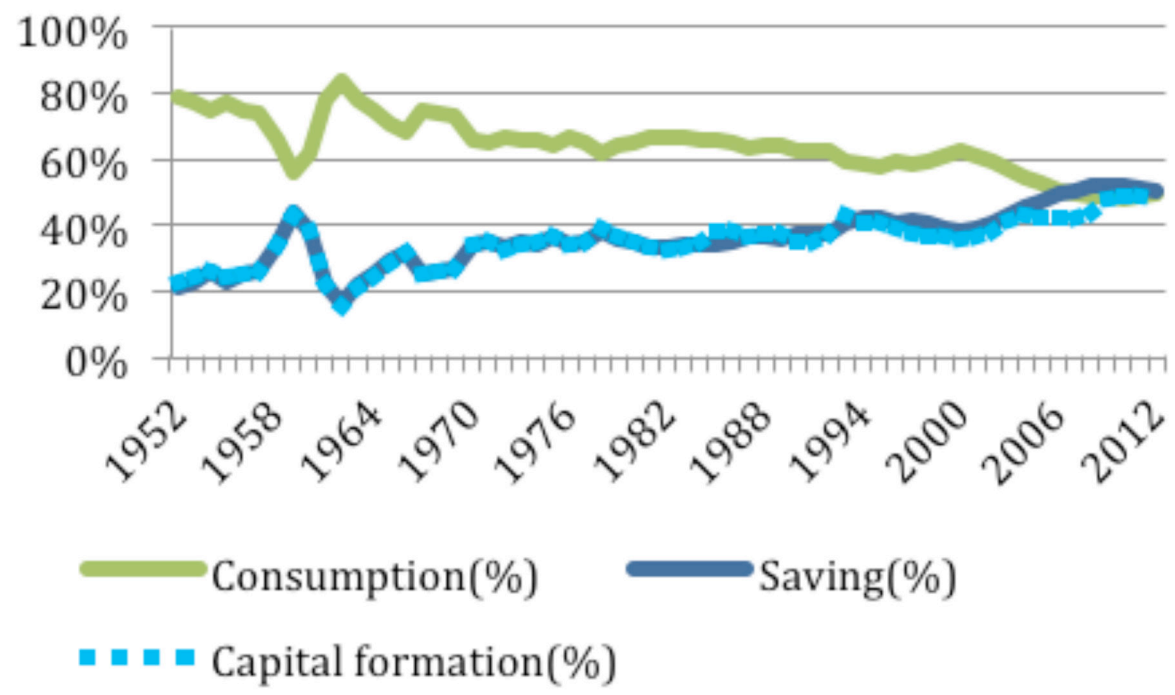

Figure 3.1 The Change in China's Consumption Rate and Savings Rate (share of GDP) in the Past Six Decades

Source: NBS (2014).

Figure 3.1 also shows that the capital formation rate tended to rise in tandem with the savings rate, and basically coincided with the savings rate most of the time; however, after the savings rate climbed to more than 40 per cent, the two began to separate, with the capital formation rate falling short of the savings rate. The difference between the two was made up for by net exports. The overcapacity problem in China's manufacturing industry was becoming more and more serious precisely during this period. This shows that a main reason for the continuous expansion of China's trade surplus in the previous period was insufficient domestic consumer demand. The continued reliance on investment stimulation couldn't fundamentally solve the problem of insufficient aggregate demand, and has instead led to overcapacity.

It is true that, during most of the past three decades, high savings provided sufficient funds for investment becoming a powerful impetus to economic growth. High saving and high investment were undoubtedly among the main driving forces behind China's rapid economic growth in this period; however, it is not true that the higher the savings and capital formation rates, the more beneficial they are to the economy. After 2000, the declining trend of the consumption rate became stronger and the growth of the savings and capital formation rates was extraordinary, which pushed the growth rate of fixed capital stock from about 10 per cent up to close to 20 per cent (calculated based on fixed assets investment data using the perpetual inventory method), but this didn't bring about an acceleration in economic growth. On the contrary, there 
has been a continuous slowdown of economic growth in the past five to six years. This shows that under the condition of ultra-high saving and investment rates, the intensification of insufficient domestic demand significantly reduced economic efficiency.

The decline in China's consumption rate in the centrally planned period (1952-78) was mainly caused by forced capital accumulation conducted by the Government to promote industrialisation. After the start of market-oriented economic reforms, however, the declining trend in the consumption rate since the mid 1980s has been closely related to changes in the pattern of income distribution for what follows.

First, during this period, economic growth was faster than income growth, leading to declining shares of both household income and household consumption. A major cause of this situation is the 'dual economy' state described by Lewis (1954) in which the 'unlimited supply' of surplus labour suppresses the rise in urban wages.

Currently, there are at least 160 million rural migrant workers employed in urban areas, as well as millions of rural workers continuing to enter urban areas each year. Therefore, the supply to the labour market has long been abundant and wage growth has been far below the growth rate of per capita GDP. This has led to a declining share of employee compensation in income distribution, and has further caused the growth of household consumption to lag behind economic growth. During the 25 years from 1985 to 2010, while China's per capita GDP increased by 8.4 times, the per capita income of urban and rural residents grew by only 6.3 and 3.6 times respectively, and per capita consumption in China increased by only 4.4 times (in constant prices).

In recent years, the above situation has been changing. Some scholars have noticed a slowdown of labour transfer from rural to urban areas and argued that China has passed the 'Lewis turning point' (Cai 2010). In addition to the changing relationship between labour supply and demand, improvement of the social security system and the increase of transfer payments also contributed to the acceleration of urban and rural income and consumption growth in recent years. During 2011-13, the annual growth rates of per capita income of urban and rural residents were 8.3 per cent and 10.5 per cent (in constant prices) and exceeded the corresponding growth rate of per capita GDP by 7.7 per cent. There were signs that household consumption growth was slightly lower than household income growth, but it still exceeded per capita GDP growth.

It should be noted, however, that nearly half of the Chinese population still lives in rural areas. Although a majority of young people work in urban areas, a large proportion of the middle-aged working population remains in rural 
areas. Furthermore, faced with institutional barriers in hukou or household registration, and access to social security, welfare and housing service systems, migrant workers find it difficult to settle there and therefore have to leave their children and parents in the countryside. Many of them have to return to their rural home after working in cities for many years. The current slowdown in labour transfers from rural to urban areas is, to a certain extent, caused by these institutional barriers. If these obstacles can be gradually eliminated through reforming the household registration system, the social security and public services systems, there will still be quite a large number of rural labourers to be transferred out.

Second, the share of government revenue in GDP declined rapidly in the 1980s and the first half of the 1990s, but it has been increasing constantly since the mid 1990s. Amongst government spending, investment in fixed assets grew fastest. During 2003-12, funds for fixed assets investment in the state budget grew at an annual rate of 22 per cent (in constant prices). Meanwhile, budgetary expenditure for public services, social security and transfer payments grew relatively slowly. This has contributed to the declining share of household consumption in GDP.

Third, the widening income disparity is an important cause of the decline in the share of household consumption. Due to the diminishing marginal propensity to consume, the savings rate of the rich is much higher than that of the poor. Table 3.1 shows that, according to the 2011 data from the NBS, the savings rate of the lowest-income urban households was less than 7 per cent, while the savings rate of the highest-income households reached 40 per cent.

Table 3.1 Urban Household Savings Rate (by income levels in 2011)

\begin{tabular}{|l|r|r|r|r|r|r|r|}
\hline & $\begin{array}{c}\text { Lowest } \\
\text { income }\end{array}$ & $\begin{array}{c}\text { Low } \\
\text { income }\end{array}$ & $\begin{array}{c}\text { Lower- } \\
\text { middle } \\
\text { income }\end{array}$ & $\begin{array}{c}\text { Middle } \\
\text { income }\end{array}$ & $\begin{array}{c}\text { Upper- } \\
\text { middle } \\
\text { income }\end{array}$ & $\begin{array}{c}\text { High } \\
\text { income }\end{array}$ & $\begin{array}{l}\text { Highest } \\
\text { income }\end{array}$ \\
\hline $\begin{array}{l}\text { Share in all } \\
\text { households (\%) }\end{array}$ & 10 & 10 & 20 & 20 & 20 & 10 & 10 \\
\hline $\begin{array}{l}\text { Per capita } \\
\text { disposable } \\
\text { income (RMB) }\end{array}$ & 6876 & 10672 & 14498 & 19545 & 26420 & 35579 & 58842 \\
\hline $\begin{array}{l}\text { Savings rate } \\
\text { (\%) }\end{array}$ & 6.5 & 20.3 & 25.0 & 28.2 & 31.3 & 32.8 & 40.2 \\
\hline
\end{tabular}

Source: NBS (2014).

During the 25 years from 1985 to 2010, China's Gini coefficient for income distribution rose from 0.31 to 0.48 and China appeared in the short list of countries with huge income disparities. The widening income gap indicates faster growth of the rich than of the poor, skewing the distribution of national income towards the minority. Therefore, the widening income gap spontaneously leads to a decrease in the consumption rate and an increase in the savings rate. 
Statistics show that the overall household savings rate (weighted average of urban and rural residents) rose from 23 per cent to 29 per cent in the decade from 2000 to 2010.

It should be pointed out that the actual income inequality and the decline of the consumption rate were more serious than the statistics show. This was in part because some of the high-income households received a large amount of 'grey income' from sources that were not declared and thus not reflected in the household income statistics. According to a study based on a nationwide survey of urban residents' income, the relative income ratio between the richest 10 per cent and the poorest 10 per cent of households was 20.9 in 2011 , while it was only 8.6 according to official statistics. The actual savings rate of highincome households was also significantly higher than that reported in official statistics. The major cause of this situation was the existence of loopholes in the management of public funds and public resources, imperfection of the institutions, low transparency, lack of social supervision, imperfection of the tax system, poor management of the capital and land markets, and the poor management of income distribution in monopoly industries. These led to the loss of public funds, corruption and unfair distribution (see Wang 2010, 2013; Wang and Woo 2011).

Fourth, during China's reforms, the wage determination mechanism changed from government administration to market mechanisms, which resulted in flexibility in employment and efficiency gains, whereas institutions which compensate for market imperfection, such as legislation for labour protection, social security and public welfare systems, were underdeveloped. These systems were developed in Europe in the nineteenth century and then in the United States after the Great Depression of the 1930s. With the social security systems missing, the growth of labour income and the growth of consumption significantly lag behind economic growth.

According to an official survey, 359 million people from rural areas were employed in urban areas in 2011, but only 216 million workers participated in the basic pension insurance scheme for urban workers, 252 million in the basic medical insurance scheme, 143 million people in the unemployment insurance scheme, and 177 million people in the industrial injury insurance scheme. The actual coverage of the above social insurance schemes for urban employees was only 60 per cent, 70 per cent, 40 per cent and 49 per cent, respectively. Those who were not covered by these urban social security systems were mainly migrant workers in the cities (NBS 2012). Due to the lack of social security, these workers have to compress their current consumption in order to save money to cope with future risks. 
Fifth, firms in a monopoly position and endowed with advantageous resources have been enjoying rapidly rising corporate income and savings, which is one reason for the decline of the household consumption rate. These industries are protected by the Government in terms of pricing, taxation and resource allocation, and so receive profit margins that are several times those in competitive industries. These industries include banking and insurance, oil and gas, telecommunications and electricity. The unreasonable allocation of the huge revenue from land development and transfer, and the insider trading and fraud in capital markets resulting from poor regulations, are also important factors.

Sixth, local governments at various administrative levels have strong incentive to promote local economic growth and often offer policy preference to large investment projects and large enterprises, while the business environment for labour-intensive small and medium-sized enterprises which create a lot of employment is relatively worse, and these firms are at a competitive disadvantage. Consequently, the income gap is further expanded and the consumption rate declines. According to the National Economic Census data, the proportion of all small industrial enterprises in total industrial output fell from 56.4 per cent to 44.2 per cent, and that in total industrial employment fell from 67 per cent to 59.4 per cent, between 1995 and 2008 (NBS various years). The atrophy of small enterprises was unfavourable to employment growth and balanced income distribution.

In recent years, wages and farmers' income have been growing relatively rapidly, which improves the situation. The final consumption rate increased from 48.2 per cent of 2010 to 49.1 per cent of 2011 and 49.5 per cent of 2012, showing a rise for the first time in more than a decade. This new phenomenon has several causes: the labour supply and demand situation has changed in recent years and wage growth has accelerated; farmers' incomes have increased due to growth in agricultural output, agricultural price increases and favourable agricultural policies; social security has been improving and government spending on public services and transfer payments to low-income residents have increased - an example being the significant rise in the minimum wage standard. In the current circumstances, however, it is still too early to regard these changes as a turning point towards structural rebalance.

\section{Insufficient consumption demand and structural imbalance}

In the past decade, the savings rate rose continuously and the consumption rate declined continuously, which significantly changed the structure of total demand, making economic growth increasingly dependent on the demand pull from foreign markets and resulting in structural imbalances. After the GFC of 
2008-09, demand from the international market remained weak, which slowed export growth markedly. This in turn prompted the Government to adopt heavily expansionary fiscal and monetary policies and to stimulate economic growth by expanding government investment, thus pushing the investment rate to higher levels. Structural imbalance can be mainly observed in the following factors.

\section{Heavy reliance on exports}

With the rise in the savings rate, the contribution of domestic final consumption to economic growth decreased. In most of the years since 2000, the contribution from domestic final consumption to economic growth has remained at about 40 per cent, whereas in the period 2000-08, the average annual growth rates of China's dollar-denominated imports and exports were 22.4 per cent and 24.4 per cent, respectively. Net exports of goods and services accounted for as much as 8.8 per cent of GDP in 2007 (but dropped to 2.8 per cent in 2012).

China's exports and trade surplus expanded rapidly after 2000. One of the reasons is the rising competitiveness and the full play of China's comparative advantages after its accession to the World Trade Organisation (WTO). Another reason was that the relative lack of domestic demand coincided with the rapid expansion of domestic production capacity so that firms could not find outlets for their products in the domestic market and were forced to turn to the international market. This last factor is, in fact, a reflection of the domestic structural imbalance.

\section{Over-reliance on investment}

From 2000 to 2011, the share of capital formation in GDP increased by 13 percentage points, from 35.3 per cent to 48.3 per cent. During the GFC from 2008 to 2010, the Chinese Government launched an expansionary investment plan of RMB4 trillion, and many local governments established platforms for large-scale financing of investment funds that involved more than ten RMB10 trillion. Bank loans were greatly relaxed in 2009, which increased by RMB10 trillion or one-third of the level of the previous year. This led to extremely eased monetary supply and rapid expansion of the scale of investment. The rate of capital formation significantly increased as a result.

Indeed, investment growth lifted up rapid economic growth in the short run. However, without corresponding household consumption growth, the rapidly expanding production capacity could not be absorbed by domestic demand and thus caused overcapacity in later periods (Table 3.2). 
Table 3.2 Capacity Usage Rate in Some Industries, 2009-12 (per cent)

\begin{tabular}{|l|c|c|c|c|}
\hline & $\mathbf{2 0 0 9}$ & $\mathbf{2 0 1 0}$ & $\mathbf{2 0 1 1}$ & $\mathbf{2 0 1 2}$ \\
\hline Electrolytic aluminium & 61.2 & 59.6 & 58.6 & \\
\hline Photovoltaics & $/$ & $/$ & $/$ & $<60.0$ \\
\hline Shipbuilding & $/$ & $/$ & $/$ & about 60.0 \\
\hline Cement & 67.1 & 65.2 & 64.5 & 67.1 \\
\hline Coke & 72.6 & 70.4 & 69.4 & \\
\hline Wind turbines & $/$ & $/$ & $/$ & $<70.0$ \\
\hline Plate glass & 69.2 & 71.4 & 77.6 & \\
\hline Crude steel & 81.1 & 82.0 & 80.5 & 72.0 \\
\hline Coal & 91.8 & 89.3 & 87.2 & $/$ \\
\hline Electricity generation & 84.2 & 86.4 & 88.6 & $/$ \\
\hline Automobiles & 85.7 & 105.0 & 94.4 & $/$ \\
\hline
\end{tabular}

Source: China Economic Information Network, internet available at <http://www.cei.gov.cn/>.

In order to avoid the problem of capacity expansion, local governments developed increasing enthusiasm for infrastructure construction and real estate development. These areas do not directly relate to production capacity, although they indirectly drive up market demand for steel, cement and other inputs, and thus stimulated the expansion of production capacity in these sectors. After the expansionary policy ended, the excess capacity became prominent.

In 2012, China's crude steel production was 724 million tonnes and the capacity utilisation rate was 72 per cent (NBS 2013; State Council 2013). This in turn forced the Government to use administrative measures to eliminate excess capacity, close businesses and destroy old equipment. This was a waste of resources. It is obvious that when the savings rate and the capital formation rate have already been high, continuous use of expansionary investment policies to stimulate demand will only have a very short-term effect and the oversupply situation will be worsened later on. Such expansionary policies have reached a dead end. Meanwhile, accompanying high inputs, high costs, high emissions, high pollution and resource and environmental degradation have all become constraints to future economic growth.

\section{Growth slowdown and decreasing returns to capital}

Investment expansion leads to overcapacity, which means part of the investment is ineffective. In Table 3.3, the annual growth rates of the Chinese economy and the fixed capital stock in the period 2000-13 are calculated and compared. We can see that, in the past 10 years, due to the rapid expansion of 
investment, the annual growth rate of capital stock has risen from 9 per cent to about 16 per cent, whereas the economic growth rate has been slowing. This shows decreasing efficiency of capital.

Table 3.3 also calculates the capital-output ratio (capital stock/GDP) and the incremental capital-output ratio ( $\Delta$ capital stock/ $\Delta$ GDP). These two indicators are the reciprocals of the average capital productivity and the marginal productivity of capital, respectively. The larger their values are, the lower is the productivity of capital. During the period 2001-12, the capital-output ratio rose from 1.97 to 3.26, while the incremental capital output ratio rose from 2.19 to 6.23.

Table 3.3 Changes in Growth Rates of China's Capital Stock and Capital-Output Ratio in the Past Decade

\begin{tabular}{|l|c|c|c|c|}
\hline & $\begin{array}{c}\text { Growth rate of } \\
\text { GDP (\%) }\end{array}$ & $\begin{array}{c}\text { Growth rate of } \\
\text { capital stock (\%) }\end{array}$ & $\begin{array}{c}\text { Capital-output } \\
\text { ratio }\end{array}$ & $\begin{array}{c}\text { Incremental } \\
\text { capital-output } \\
\text { ratio }\end{array}$ \\
\hline 2000 & 8.4 & 9.1 & 1.95 & 2.09 \\
\hline 2001 & 8.3 & 9.3 & 1.97 & 2.19 \\
\hline 2002 & 9.1 & 10.2 & 1.99 & 2.22 \\
\hline 2003 & 10.0 & 12.2 & 2.03 & 2.42 \\
\hline 2004 & 10.1 & 13.1 & 2.08 & 2.63 \\
\hline 2005 & 11.3 & 13.9 & 2.13 & 2.57 \\
\hline 2006 & 12.7 & 14.9 & 2.18 & 2.51 \\
\hline 2007 & 14.2 & 15.2 & 2.20 & 2.34 \\
\hline 2008 & 9.6 & 14.8 & 2.30 & 3.38 \\
\hline 2009 & 9.2 & 18.0 & 2.48 & 4.48 \\
\hline 2010 & 10.4 & 17.5 & 2.64 & 4.15 \\
\hline 2011 & 9.3 & 16.3 & 2.81 & 4.64 \\
\hline 2012 & 7.7 & 16.0 & 3.03 & 5.87 \\
\hline 2013 & 7.7 & 15.8 & 3.26 & 6.23 \\
\hline
\end{tabular}

Source: NBS (2014).

The sharply rising trend of the capital-output ratio is significantly different from the path experienced by developed countries. In Figures 3.2a and 3.2b, the capital-output ratio of China in the past 60 years (1952-2011) is compared with the average capital-output ratio of the 22 developed countries in the Organisation for Economic Cooperation and Development (OECD) during the period 19602001 (Australia, Austria, Belgium, Canada, Denmark, Finland, France, Germany, Greece, Iceland, Ireland, Italy, Japan, Netherlands, New Zealand, Norway, Portugal, Spain, Sweden, Switzerland, the United Kingdom and the United States). 


\section{OECD}

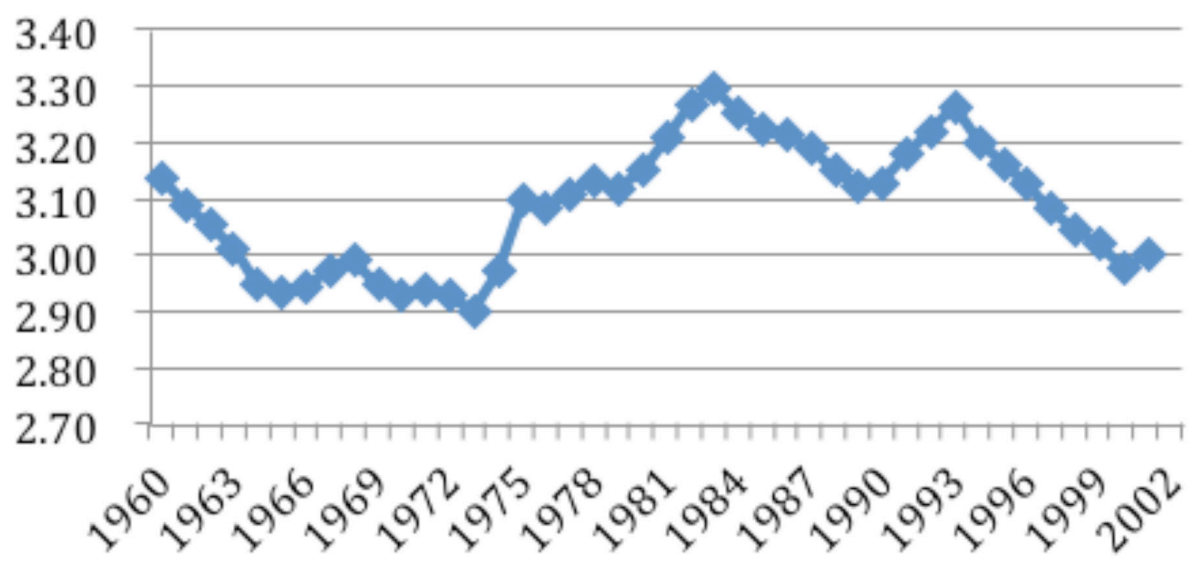

Figure 3.2a Average Trend in the Capital-Output Ratio of 22 OECD Countries

\section{China}

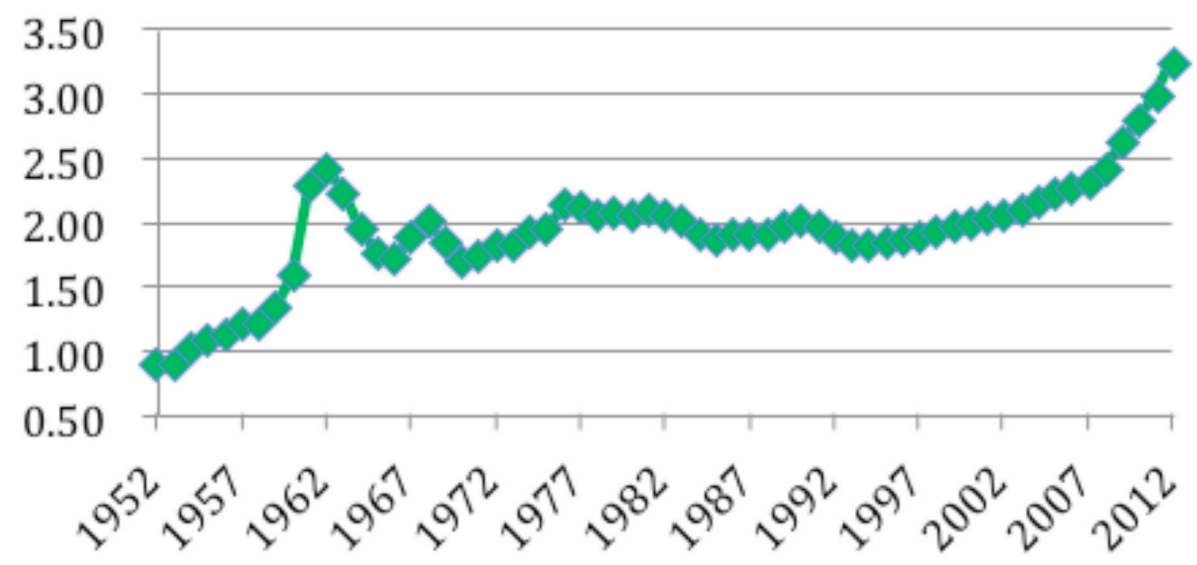

Figure 3.2b Long-Term Trend in the Capital-Output Ratio of China Sources: Kamps (2004); and authors' calculations.

Comparison of the data shows that the capital-output ratios in China and in the OECD countries have the following differences in their long-term trends. 
First, the average capital-output ratio in OECD countries fluctuated within a smaller range of 2.9-3.3 in the 42 years. For most of the countries, the bandwidths of fluctuation did not exceed one. In contrast, China's capital-output ratio increased from 1.5 to 3.3, and the range of the fluctuation is significantly larger.

Second, on average, the OECD countries' capital-output ratio did not rise continuously (or capital productivity fall continuously). During the three oil crises (1973-93), the average capital-output ratio was relatively high, with a peak at 3.3, but then dropped significantly after 1993. Until 2001, the average capital-output ratio had dropped to three. China's capital-output ratio, in contrast, has been rising continuously from the mid 1990s to the present.

Third, China's rising capital-output ratio is in some way related to its industrialisation process because the marginal productivity of capital will gradually decrease with increasing capital intensity in a capital-scarce earlystage developing country. This is reasonable in the industrialisation phase. China has not yet completed its industrialisation process, while the OECD countries have already finished theirs. Nevertheless, China's capital-output ratio was close to 3.3 in 2012, which was significantly higher than the current average level of the 22 OECD countries. For a middle-income country, this indicates that capital productivity has dropped too much. This occurred mainly in the past 10 years, reflecting the efficiency problems on China's development path in the past 10 years.

The above situation is not only related to China's expansionary fiscal and monetary policies over the period of the GFC, but also to the overenthusiasm of local governments at various levels towards pursuing GDP growth rates. Governments at various levels use various measures to attract foreign and domestic investment, such as tax reduction, cheap land prices, etc. or directly borrowing bank loans via so-called 'financing platforms' to finance various government investment projects regardless of costs. All of these practices lead to over-investment. If these conditions cannot be changed, the current structural imbalances and lack of domestic demand will be difficult to alter, and may even become more severe. Economic growth is likely to follow a downward trend into long-term weakness, and even into the middle-income trap.

On the other hand, the Chinese economy still has enormous growth potential. Currently the urbanisation rate is just more than 50 per cent and urbanisation will remain a powerful engine of growth, with another 20 years of rapid development. The process of industrial upgrading is taking place and has yet to realise its full potential. The development of the service sector is still inadequate. Both of these have great room for further development. The quality of human capital should be improved. The rate of technological progress hasn't 
yet reached the ideal speed, but there is great potential for catching up with technologies in developed countries. If the education and innovation systems can be improved, there is great potential for total factor productivity to grow.

For these institutional potentials to become the driving force of development, however, the obstacles need to be removed, and the economic structure needs to be rebalanced. A key to achieving these is to rebalance savings and household consumption to enable domestic demand to become a powerful engine for sustained economic growth.

\section{Is there a 'golden-rule savings rate'?}

According to Keynesian theory, a country's overall economic need comprises three parts that are substitutable with each other: consumption, investment and net exports. When there is insufficient aggregate demand (total investment $<$ total savings) and it causes a shrinking economy, the aggregate demand can be increased by consumption expansion, the use of expansionary fiscal policy to increase government investment or easing of monetary policy to stimulate private investment. Since the household savings rate is unlikely to be determined by the Government, the fiscal and monetary policies of the Government emphasised by Keynes are basically focused on adjusting investment demand.

China twice adopted the Keynesian demand expansion policy to substantially increase investment and successfully boosted its economic growth when hit by both the Asian financial crisis in 1997-98 and the GFC in 2008; however, the inflation that occurred after the last substantial expansion, overcapacity and the steadily declining rate of economic growth prompt us to reflect on the long-term effectiveness and applicability of Keynesian policies in China.

\section{The conditions for suitability of expansionary investment policies}

Despite the fact that Keynesian theory has had many successful applications, it did not investigate the conditions under which total investment being less than total savings occurs. Macro-economic analysis shows that there is a correlation between investment and savings. If financial markets are sufficiently flexible then when the social savings rate is high enough and money supply is sufficient, interest rates will stay low, so that the scale of investment is automatically maintained at a high level. If, however, investment is still lower than savings now, this is probably due to market saturation, overcapacity and the absence of profit margins for investors. This situation is especially evident in a lowconsumption, high-savings and high-investment economy like China's. 
In this case, if government intervenes through fiscal policy to expand investment or through accommodative monetary policy to stimulate investment, can new demand be created? The answer is: yes, but only in the short term. New investment projects will inevitably generate new demand for investment goods, creating more purchasing power to drive short-term economic growth; however, this process doesn't end here, because once the new investment project is completed, production capacity will be expanded. So, after a short-term expansion of demand, the future supply will be further expanded. If consumer demand remains unchanged at this time, or consumption growth lags behind the growth of output, it means that the total savings rate rises rather than falls, thus creating new savings that need to be balanced by investment on an even larger scale. Thus, a larger round of expansionary fiscal or monetary policy needs to be started next round.

No sophisticated economic analyses are required for one to see clearly that without a certain balance between consumption and savings, the investment-led growth cycle is not sustainable. Thus we can easily understand why Keynesian expansionary policies are often able to achieve good results in the short run, but their effects often diminish in the medium and long runs, leading to the difficult situation of stagflation.

Is there a better alternative available to the Government? The answer is yes. It would be better for the Government to promote infrastructure investment and not productive investment. This is because investment in infrastructure does not directly create or expand production capacity. In this sense, to respond to the economic crisis caused by overcapacity, fiscal policy could be more effective than monetary policy in terms of long-term effects. Fiscal policy can be chosen to target certain directions of investment - mainly infrastructure construction. In contrast, an expansionary monetary policy stimulates economy-wide investment, resulting in a further increase in total supply.

There is, however, still a reasonable limit to fiscal policy even if it is used only in infrastructure. First, oversupply in infrastructure will lead to long-term idleness and waste of resources - a kind of overcapacity as well. Such investment drives GDP growth in statistics but does not bring about additional national welfare. Second, expanding the scale of infrastructure investment is bound to increase demand for inputs and upstream demand along the industrial chain. If a certain limit is exceeded, further increases in investment and production capacity will take place in related industries. Once the expansion ends, the newly created production capacity will become excessive.

In China in the past 20 years, the Government has promoted infrastructure construction, which indeed significantly promoted economic growth. In recent years, however, various businesses and industries have suffered 
from increasingly serious overcapacity, and the situation is most severe in the production of inputs such as iron, steel, cement, and so on. This is clearly the result of large-scale expansion of infrastructure investment. In the initial period of expansion, the demand for steel and other inputs is strong and prices rise, thus conveying wrong signals to these industries and prompting them to make significant investment to expand production capacity. Once expansionary policies come to an end, this newly created production capacity will become excessive.

\section{Is there a 'golden rule' for saving and investment?}

The situation described above shows that consumer demand and investment demand are not always substitutable. The higher the savings rate, the higher is the required rate of investment to maintain the balance of supply and demand, and the faster is the expansion of production capacity. The small scale and slow growth of domestic consumption are insufficient to absorb the increase of final output due to the expansion of production capacity. This will continue to generate a new supply-demand imbalance.

Therefore, for an economy to maintain structural balance and sustainable development, a reasonable savings rate is required. A very low savings rate will not be sufficient for funding investment and therefore for economic growth. On the other hand, if the savings rate is too high, production capacity will grow faster than consumption and this will continue to increase the investment rate and create new overcapacity. Consequently, economic growth will suffer as well.

Robert Barro and Xavier Sala-i-Martin (1995), both working in economic growth theories, prove that, under steady-state growth conditions, there is an optimal savings rate to ensure the maximisation of residents' long-term consumption. They call it the 'golden-rule savings rate'. The savings rate is not, however, a definite value, and it depends on the growth rates of labour and capital depreciation and other external conditions.

Here we apply a simple approach - a two-sector model - to examine the relationship between the savings rate and economic growth.

Suppose an economy consists of two basic production sectors. Sector A produces consumer goods for the whole of society and Sector B produces capital goods for both Sector A and Sector B. Each year the entire society will use 70 per cent of total output in consumption and 30 per cent of total output in investment. Therefore, the total output consists of 70 per cent consumer goods and 30 per cent capital goods. For simplicity, we assume that the marginal productivity of the two sectors is the same and equal to their average 
productivity; their capital intensity and labour intensity are the same; and the whole economy is initially in supply and demand equilibrium. Thus, Sector A should have 70 per cent of the capital and labour in the whole society, while Sector B owns the remaining 30 per cent.

Now assume that some external shock drives up the gross savings rate from 30 per cent to 50 per cent. Consumer demand declines correspondingly (a decline of 50 per cent/70 per cent $-1=-28.6$ per cent). The society reduces consumption but has more money for investment. The decline in consumer demand first causes overcapacity in Sector A. In response to market signals, labour and capital flow into Sector B, causing the production capacity in Sector A to shrink and the production capacity in Sector B to expand. In the meantime, the increase in the savings rate brings more capital for investment in Sector B than in Sector A.

If, however, the actual restructuring process happens like this, the production overcapacity in Sector B will become more serious than that in Sector A. This is because with the decline in output of Sector A, the demand for capital goods from Sector A will decrease by the same proportion after a certain time lag, so that total demand for capital goods decreases by 20 per cent $(=-28.6$ per cent $\times 70$ per cent). This will force Sector $B$ to reduce production and further reduce the demand for capital goods from Sector B, leading to a 27.6 per cent shrinkage in the demand for capital goods. Therefore, the transfer of capital and labour from Sector A to Sector B and the new investment in Sector B are unlikely to be accomplished. Both sectors will experience overcapacity and a decline in production, leading to rising unemployment and a decline in revenue. In the first round of the fall, aggregate demand shrinks by 27.8 per cent (that is, the weighted average of the extents of declines in consumer demand and in investment demand), while the ensuing unemployment and decline in revenue, in turn, will lead to further declines in demand for consumer goods. Without other intervening factors, this vicious cycle will drag the whole economy into a downward spiral towards a state of crisis.

Now suppose that the Government implements policies to stimulate investment demand immediately after the first round of declines. To compensate for the previous 27.8 per cent of decline in total demand and to reinstate the level of aggregate demand, it is necessary that the demand for capital goods is raised by 92.7 per cent (using the level of demand for capital goods before its drop as 100 per cent). Assuming this goal can be achieved, the total output will then return to its pre-crisis level-but this is only a short-term effect. Large-scale investment will bring about the rapid expansion of the production capacity of the two sectors. After the investment cycle induced by the economic stimulus is completed, total demand is no longer expanding, while the total supply of new production capacity increases significantly. This will lead to a 
new round of overcapacity and the economy will again face a crisis of insufficient aggregate demand. Unless the economy-wide savings rate can be reduced to its original level or the society can export part of its output to other countries and thus maintain a long-term trade surplus, accommodative monetary policy is ineffective in the medium to long term.

Now we consider another scenario: add a public sector to the above model, and assume that the Government, instead of taking the accommodative monetary policy to stimulate investment, simply adopts an expansionary fiscal policy in the form of infrastructure investment by the public sector. In this case, the effective demand will increase due to the expansion of investment, but the new investment will not lead to further expansion of production capacity. The economy can recover from the crisis and the situation will be better than in the previous case. After the economy recovers to its pre-crisis status, however, consumer demand is still only 50 per cent of the total output, while the other 50 per cent of total output still relies on investment demand. Public investment to expand domestic demand has, however, already been completed and the demand for capital goods cannot be sustained at the level of the expansionary period. Therefore, if society cannot adjust its saving and consumption rates, the economy will again face the difficulty of insufficient aggregate demand once the expansionary public investment stops. This will force the government to continue relying on deficit financing to maintain investment expansion, which ultimately leads to stagflation.

The above analysis shows that, under certain conditions, there exist optimal consumption and saving rates. When the consumption rate is higher than the optimal level, savings, investment and capital-embodied technical progress are inadequate, leading to slow economic growth. When the consumption rate is lower than the optimal level, the demand is insufficient, which also restrains economic growth, makes the actual growth rate lower than the potential growth rate and results in loss of efficiency. In the medium to long run, very low consumption cannot be continuously compensated with investment expansion.

The policy implication of the above analysis is that when there is a lack of consumer demand, neither accommodative monetary policies nor the expansion of government-led investment can solve the fundamental problem. The key is to change the low consumption rate through institutional reforms and policy adjustments. In China, necessary and effective measures to change the consumption rate include reforming the aspects of the fiscal and taxation systems that are not entirely reasonable, rationalising government spending, reforming government management systems to improve government behaviour and to promote the rational allocation of factors, improving social security, public services and income redistribution systems, and narrowing the excessively wide income gap. 
Before and after World War II, all of the developed countries improved social security, public services and income redistribution systems. These changed the situation of a polarisation of income distribution characterised in early capitalist economies and protected the basic rights of citizens for education, employment, fair compensation, access to health care, unemployment insurance and pensions, which significantly changed the large income gap and insufficient household consumption characterised in early capitalist economies. This diminished the occurring of cyclical economic crises often observed in traditional capitalist economies.

Until now, debates on the relative importance of equity and efficiency and of public welfare and free markets are continuing widely without a common conclusion. Looking back, most people would agree that the changes in income distribution and social welfare systems in the twentieth century were precisely what gave the advanced market economies new life and helped them avoid a recurrence of the Great Depression of the 1930s. The relationship between equity and efficiency is not mere substitution. This indicates there are structural imbalances due to unduly large income inequality, and improving income distribution and fairness in society will not only improve the allocation of resources, but also promote efficiency.

\section{What are reasonable levels for the savings rate and consumption rate?}

Although the existence of a 'golden-rule savings rate' can be proven, the reality differs across countries and therefore there is not a single optimal solution. Wang et al. (2009) did some preliminary econometric analyses using China's historical data for the past half-century. They use a Lucas-type growth model (Lucas 1988) and include a number of structural variables such as research and development spending, infrastructure conditions, market-oriented reforms, urbanisation, trade dependence, the final consumption rate, and so on. They found that the relationship between the final consumption rate and total factor productivity is a nonlinear function. The consumption rate being too high or too low has adverse effects on productivity and therefore on economic growth. Thus optimal band for the consumption rate is found.

The above study also finds, however, that the consumption rate is sensitive to model specifications and that its exact optimal location is not confirmed. After using the updated data, they obtain the curve shown in Figure 3.3 based on the same model. In this figure, the horizontal axis, fc, represents the consumption rate (share of final consumption in GDP); the vertical axis, $\mathrm{f}(\mathrm{fc})$, shows the effect of the consumption rate on constant price GDP value. In the figure we can find 
a maximum point where the impact of the consumption rate on total factor productivity and total output is largest, and therefore the consumption rate at this point can be defined as the optimal consumption rate.

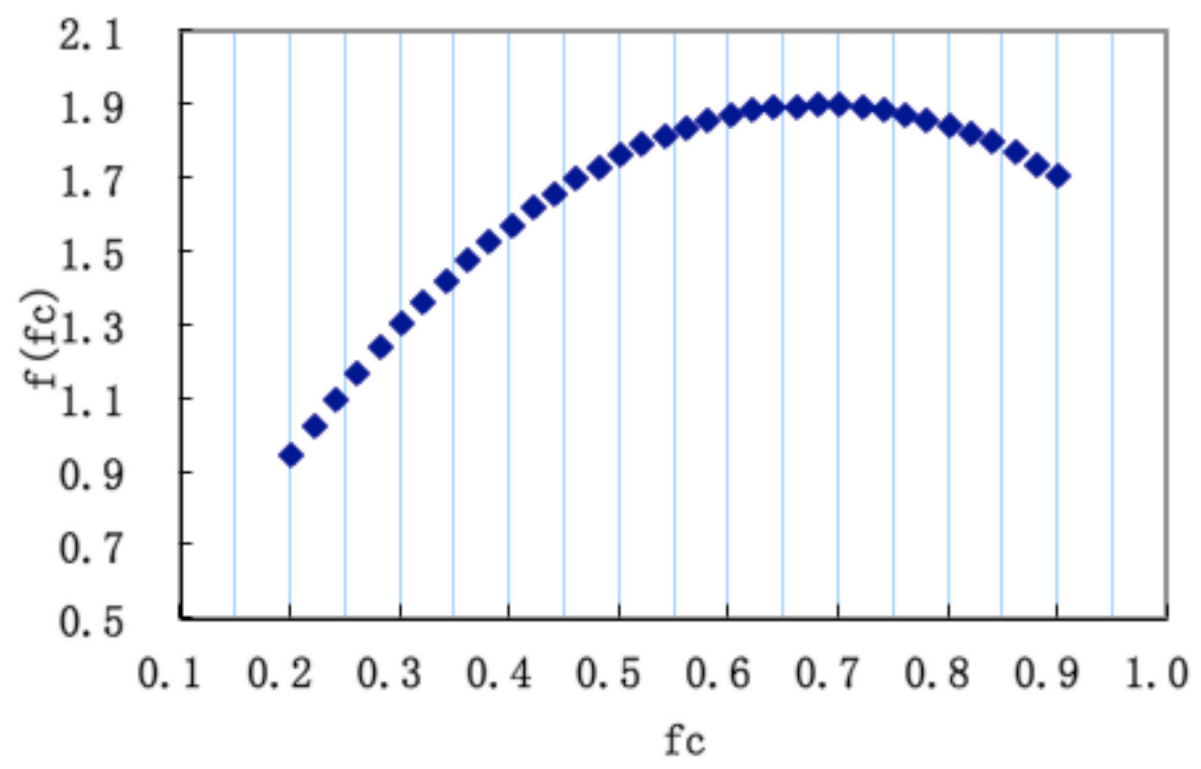

Figure 3.3 Fitted Curve of the Regression Model for the Optimal Consumption Rate

It can be seen in Figure 3.3 that the optimal consumption rate is about 60 70 per cent. Sensitivity analysis shows that the optimal point is still sensitive to model specification, changing with different model specifications. Therefore it is difficult to confirm the specific value; however, according to the analyses of empirical data from home and abroad, 60-70 per cent should be a reasonable range.

\section{Conclusion}

We may imagine economic rebalance will take place in China in the coming decade via institutional reforms and policy adjustments, to increase the final consumption rate from the current level of below 50 per cent to about 60 per cent (of GDP) and decrease the rate of capital formation from the current 48 per cent to 38 per cent and the trade surplus falls to less than 2 per cent. If these changes take place and other conditions remain unchanged, the economic growth rate will be higher than it is currently and the higher level of growth will be sustained in the longer term. Assuming these adjustments will take five years, 
during which the average growth rate is $7-7.5$ per cent, to finish, it will not be difficult to achieve an 8 per cent growth rate for China in the following ten years.

More importantly, this growth rate will, however, be achieved with less investment, less resource and energy consumption, less pollution and environmental damage, and higher household income and consumption levels. Obviously, it will be a more sustainable, more efficient, and more welfareenhancing state of growth.

\section{References}

Barro, R. and Sala-i-Martin, X. (1995), Economic Growth, New York: McGraw-Hill.

Cai, F. (2010), 'Demographic transition, demographic dividend and the Lewis turning point', Economic Research (4).

Chow, G. C. (1993), 'Capital formation and economic growth in China', Quarterly Journal of Economics (108): 809-42.

First Financial Daily (2012), 'Overcapacity being one-third, the more you invest in the iron and steel industry, the more you lose', First Financial Daily, 18 April 2012.

Kamps, C. (2004), New estimates of government net capital stocks for 22 OECD countries 1960-2001, IMF Working Paper 04/67, International Monetary Fund, Washington, DC.

Lewis, W. A. (1954), 'Economic development with unlimited supplies of labor', Manchester School of Economic and Social Studies (XXII) (May): 139-91.

Lucas, R. E. (1988), 'On the mechanics of economic development', Journal of Monetary Economics 22: 3-42.

National Bureau of Statistics (NBS) (2012), 2011 Monitoring Report of the Survey of Migrant Workers, Beijing: National Bureau of Statistics.

National Bureau of Statistics (NBS) (2013), 2013 National Economic and Social Development Statistics Bulletin, Beijing: National Bureau of Statistics.

National Bureau of Statistics (NBS) (various years), <http:data.stats.gov.cn/>.

State Council (2013), 'A Guideline for Defusing the Serious Overcapacity Problem', The Central Government website. 
Wang, X. (2010), Gray Income and Income Distribution: Comparison, Beijing: CITIC Publishing House.

Wang, X. (2013), Gray Income and Income Distribution: 2013 Report, Comparison, Beijing: CITIC Publishing House.

Wang, X. and Woo, W. T. (2011), 'The size and distribution of hidden household income in China', Asian Economic Papers 10(1), Cambridge, Mass.: MIT Press.

Wang, X., Fan, G. and Liu, P. (2009), 'China's economic growth mode transformation, and sustainability of growth', Economic Research 1.

World Bank (2012), World Development Indicators, [Chinese version], Beijing: China Finance and Economics Publishing House.

Zhang, J., Wu, G. and Peng, Z. (2004), 'China's provincial capital stock estimates: 1952-2000', Journal of Economic Research (10). 
This text taken from Deepening reform for China's long-term growth and development, edited by Ligang Song, Ross Garnaut, Cai Fang, published July 2014 by ANU Press, The Australian National University, Canberra, Australia. 